\title{
Sharing housework can be healthy: cultural and psychological factors influencing men's involvement in household maintenance
}

Following gender prescriptions can affect individuals' quality of life. Research has shown that the unequal distribution of household labor is correlated with low psychological well-being and family conflict. Therefore, negotiations concerning household and family duties within relationships appear to be an important health-related issue. Additionally, research has shown that couples who have more gender-egalitarian arrangements within their households have better health outcomes if the wider society is more gender egalitarian.

In this literature review, we aim to shed light on the relationship of the equal division of housework between women and men with their health and well-being. We also present selected results from the series of studies conducted during our PAR Migration Navigator project, which explores the practices of gender equality within households and their relationship to individual well-being among Polish couples living in Poland, Polish migrant couples living in Norway, and Norwegian couples living in Norway.

KEY WORDS

gendered household duties; gender equality and health; gender stereotypes and health 
As we approach a new century - and a new millennium - it's the men who have to break through to a new way of thinking about themselves and society. Too bad women can't do it for them, or go much further without them.

Betty Friedan "Metamorphosis" The Feminine Mystique (1997, p. XV)

\section{HOUSEWORK, GENDER ROLES, AND HEALTH}

Kosakowska-

Berezecka,

Lubomiła

Korzeniewska,

Marta

Kaczorowska

Women's increased participation in the labor market has not resulted in the equal distribution of household chores between men and women (Öun, 2012; Lammi-Taskula, 2008; Voicu, Voicu, \& Strapcova, 2009). Although there is a noticeable convergence in the amount of time spent by partners on household chores, remaining inequalities in the paid-to-unpaid work ratio consistently favor men, who devote significantly more time to professional work than household maintenance (Bonke \& Jensen, 2012). This invisibility of men in domestic chores reflects the demands embedded within gender prescriptions for men to pursue professional careers and for women to focus more on house and family (Heilman, Wallen, Fuchs, \& Tamkins, 2004; Rudman, Moss-Racusin, Phelan, \& Nauts, 2012; Wood \& Eagly, 2012). Following gender prescriptions, though, can affect individuals' quality of life. Research has shown that the unequal distribution of household labor is correlated with low psychological well-being and family conflicts. Therefore, negotiations concerning household and family duties within relationships appear to be an important health-related issue (Kil \& Neels, 2014; Lammi-Taskula, 2008).

Although some theorists have associated gender equality with men's loss of status and power (e.g., by sharing housework and becoming more domestic, men risk their professional careers) (cf. Rudman \& Mescher, 2013), an analysis by Holter (2014) demonstrated the opposite. He examined gender equality variables and potential health effects using a database with a sample from European countries and the United States drawn from the Gender Gap Index, Social Watch Gender Equality Index, United States Gender Equality Index (USGEI), United States Women's Autonomy Index, gross domestic product (GDP), and Gini index. Holter (2014) showed that gender equality brings more positive effects for men than expected and that men's importance in gender equality has been so far neglected in research lines. The results indicate that living in a gender-equal region of the world increases the chances of men's feeling happy and decreases the chances of being depressed regardless of men's income or class (Holter, 2014). Gender equality in the family has also been strongly linked to: 1) greater relationship satisfaction and well-being among both women and men (Holter, Svare, \& Egeland, 2009); 2) lower divorce rates and higher sexual satisfaction, and 3) fewer men being victims of violent deaths (the rate is lower in gender-egalitarian countries) (Holter, 2014). The benefits of gender equality for men have also been reflected in other data showing that, with higher gender equality, the gender gap in life expectancy gets smaller (cf. Scambor, Wojnicka, \& Bergmann, 2013), and male suicide decreases (Holter, 2014). Moreover, couples who have more gender-egalitarian arrangements within their households have better health outcomes if their larger society is more gender egalitarian (Holter, 2014). This indicates that cultural factors play a significant role in the relationship between gender equality levels and health-related benefits for both women and men.

As men's role in country's gender equality levels has been so far overlooked (cf. Holter, 2014; Croft, Schmader, \& Block, 2015) the overall goal of this article is to present a detailed analysis of the cultural and psychological factors related to men's greater involvement in housework and the relationship of these factors with men's well-being and health outcomes. We consider this line of research to be highly important because the gender inequality present in the labor market is still perpetuated because men do not stay at home and do not share more household duties with women. Even when in dual-career relationships, both genders follow a gender-congruent path. As a result, women enter the workforce not with equal power but with more limiting family obligations than men (cf. Kosakowska-Berezecka et al., 2016a). Allowing men to be involved in housework could be of crucial importance in fostering gender equality because women would have more opportunities to pursue professional careers. This change could also lead to higher quality of life and health-related benefits for both partners (cf. Holter, 2014). However, there exist certain barriers to men's involvement in household duties resulting from gender stereotypes perpetuated by cultural norms.

So far, the majority of studies in this field have focused on men's involvement in parenting (Astone $\&$ Peters, 2014) or the general reasons for men's underrepresentation in communal roles (Croft et al., 2015). In this paper, however, we focus on the issue of housework and the factors which influence the unequal distribution of household duties between women and men.

\section{WHY DO MEN RESTRAIN FROM HOUSEHOLD DUTIES?}

The extent to which the division of labor between women and men is perpetuated depends on the lev- 
el of gender equality in a given country. Biosocial construction theory (Wood \& Eagly, 2010, 2012) holds that, across societies, the division of labor between women and men is maintained through gender-role beliefs that justify and normalize the division. These beliefs concerning masculinity and femininity follow fixed and interrelated lines which express gendered associations: agency-career-men and communality-family-women (Wood \& Eagly, 2012). Research has shown that stereotypes of women as communal and men as agentic are weaker in societies with higher levels of gender equality, where women and men are allowed to perform similar roles in society (Glick \& Fiske, 2001; Wood \& Eagly, 2012). However, if men live in an environment where family and career are assigned to men and women respectively, then men tend to follow a gender-congruent path. To meet the masculine standards of agency, men must avoid feminine tasks for several reasons: 1) economically, involvement in the feminine, domestic world does not allow men to fulfil their duty to be the breadwinner of the family; 2) interpersonally, a communal man can be seen negatively by others (backlash effect) (Rudman et al., 2012); and consequently, 3) the high agency standards set for men can make them sensitive to threats to their masculinity (Bosson \& Vandello, 2011; Caswell, Bosson, Vandello, \& Sellers, 2014; Croft et al., 2015; Kosakowska-Berezecka et al., 2016a). Hence, if men perform feminine tasks (e.g. household duties), they might be perceived as insufficiently manly. Consequently, to preserve their manhood, they refrain from entering the domes- tic realm, follow gender stereotypical norms, and perform unhealthy behaviors. This trend, in turn, maintains the inequalities in the system and perpetuates the unequal gendered division of household tasks. As a result, men do not benefit from being more involved in household maintenance. A summary of this model is presented in Figure 1.

\section{CULTURAL NORMS AND MEN'S INVOLVEMENT IN HOUSEWORK}

Overall, men's share of household duties clearly tends to increase with social policies targeted at more gender-equal welfare regulations, especially in countries where gender egalitarianism is considered to be of value (Scambor et al., 2013; Holter, 1997). Thus, male participation in household tasks is sensitive to the cultural context (Fuwa, 2004; Geist, 2005; Yodanis, 2010). In southern European countries, men tend to avoid domestic tasks, whereas Nordic social democracies and liberal, English-speaking countries are more likely to breed gender-egalitarian husbands who participate in stereotypically feminine domestic tasks (cf. Tai \& Treas, 2013).

Men's eagerness to share household duties also varies from country to country by how important paid work is considered to be (Work Culture Index; see Thébaud, 2010). Men from countries which rank high on the Work Culture Index undertake significantly fewer household chores than men from neutral work cultures (Thébaud, 2010; Hewitt, Craig, \& Baxter, 2012). A cross-national analysis by Thévenon
Sharing housework can be healthy

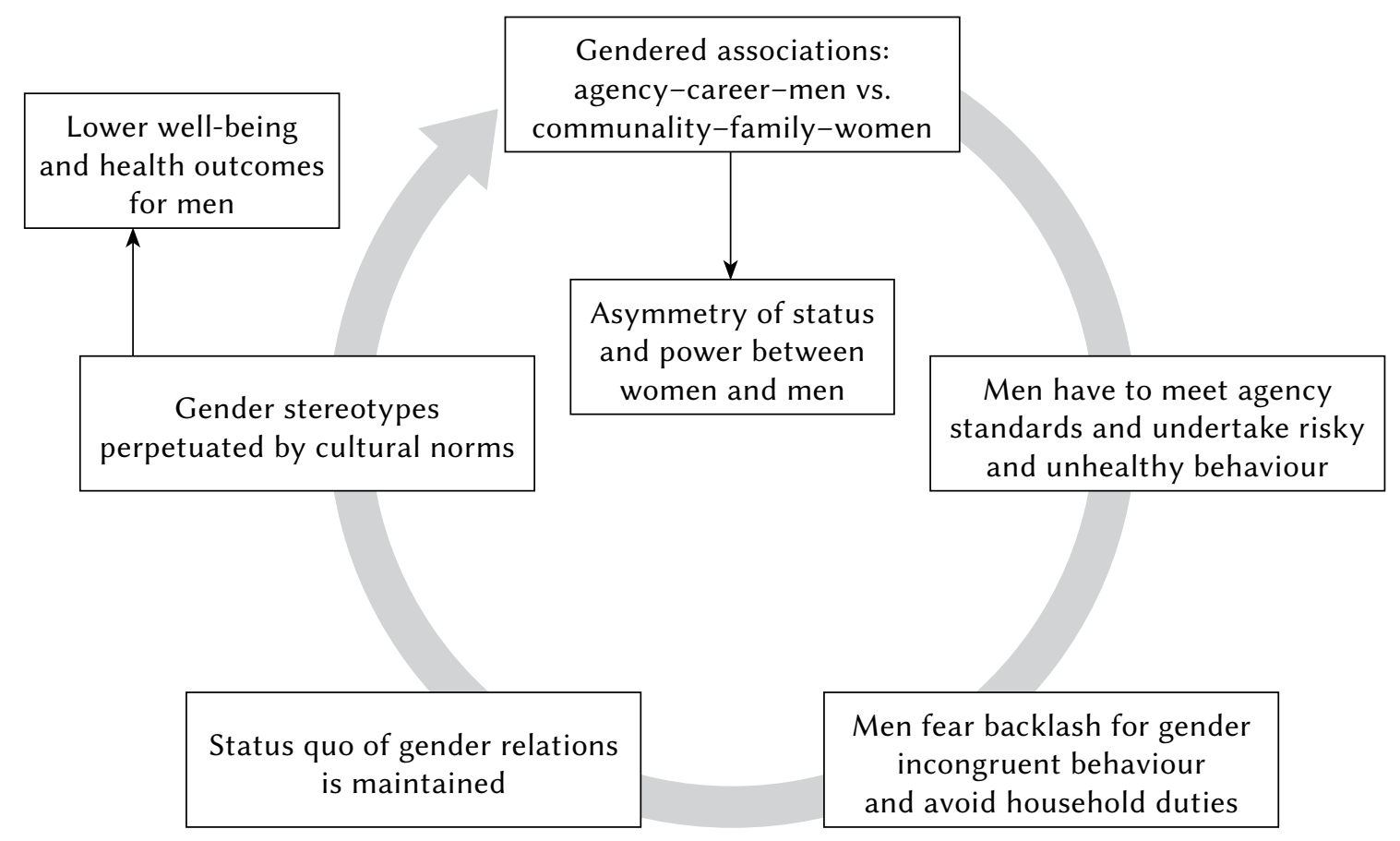

Figure 1. Model path explaining men's low involvement in household maintenance. 
(2011) showed that support for the working parents of young children (younger than age 3) (a case of Nordic countries) encourages men's involvement in performing household duties (Thévenon, 2011). These results might be explained by certain psychological mechanisms which account for variations within perceptions of what gender is.

If both sexes are present in the domestic and professional areas of life in relatively equal proportions, then their sex traits are perceived as similar. Nevertheless, even in countries where gender differences are decreasing within most masculine attributes, a corresponding shift in feminine attributes is not visible (Wood \& Eagly, 2012). Although men spend more time on housework and childcare, women still dominate domestic work (Bianchi, Robinson, \& Milkie, 2006; Kan, O’Sullivan, \& Gershuny, 2011). As other research has indicated, "[w]omen invest fewer hours in housework in countries that achieved greater gender earning equality... and in more egalitarian countries" (Strier \& Lewin-Epstein, 2007, p. 247), but that does not necessarily indicate that men devote more time to household chores (Strier \& Lewin-Epstein, 2007). When we review the reasons why men willingly engage in household chores, it appears that husbands with less traditional gender-role attitudes are more likely to do female-typical housework in general (Baxter, 1992). Similarly, couples who have a more egalitarian approach toward life and the division of duties do indeed distribute them more equally. They seem to see their household division of labor as a team project requiring team efforts (Kosakowska-Berezecka, Żadkowska, Gajewska, Wroczyńska, \& Znaniecka, 2016b).

\section{DEMAND FOR MEN TO FULFIL STANDARDS OF AGENCY}

Especially in masculine, individualistic cultures, being a man imposes high demands to be agentic (Cuddy et al., 2015). This, in turn, prescribes that men should attain high status in society by achieving success in professional life (Prentice \& Carranza, 2002; Rudman et al., 2012). This almost universal model of "the real man" is mostly associated with risk-taking, toughness, rivalry, and emotional restraint (World Health Organization [WHO], 2010; Moss-Racusin, Phelan, \& Rudman, 2010). The pressure on men to fulfil the social demands of emotional restraint and power displays can be detrimental to their mental and physical health (European Institute for Gender Equality [EIGE], 2012). Social pressure and a lack of emotional support are documented factors contributing to mental illnesses in males (United Nations [UN], 2011; WHO, 2010). Men often report trouble seeking needed medical and psychological help because according to the dominant masculinity model, asking for help is a sign of weakness and thus deprives men of their true manhood (Vogel, Heimerdinger-Edwards, Hammer, \& Hubbard, 2011; Johnson, Oliffe, Kelly, Galdas, \& Ogrodniczuk, 2012). A WHO report on gender equality (2010) underlined the necessity of a transformation toward an egalitarian-partnership model of the family, with both partners involved in domestic work.

A study by Laurin, Kay, and Shepherd (2011) showed that people tend to specially apply gender stereotypes to themselves after experiences which remind them of gender inequalities. Hence, if the culture in which individuals live emphasizes gender differences and gendered role division, both men tend to describe themselves through the lenses of gender stereotypes which follow societal expectations for men to be agentic (Amanatullah \& Morris, 2010; Moss-Racusin et al., 2010). Manhood needs to constantly demonstrated (Bosson \& Vandello, 2011; Vandello, Bosson, Cohen, Burnaford, \& Weaver, 2008), so failing to live up to masculine agentic prescriptions by equally sharing housework threatens men's masculinity. To help within the household, men might have to seek work-life balance arrangements at work, but this could lead to negative consequences for their manhood. Consequently, men fear not being perceived as sufficiently manly and refrain from performing female-typed activities. Avoiding housework can be one of the ways in which males compensate for threats to their masculinity and maintain their high standards of self-perceived agency (Bosson \& Vandello, 2011; Caswell et al., 2014; Kosakowska-Berezecka et al., 2016a).

In one of our studies, we showed that agency has a very important role in men's self-description and constitutes certain psychological barriers to their involvement in domestic roles. Threatening men's status (in our studies, we provided 76 male students with feedback about their testosterone level) leads men who think they are not manly enough (low testosterone levels) to express more traditional views of gender relations and parental roles than men who think that they have high levels of testosterone (study 1, Kosakowska-Berezecka et al., 2016a). It thus is clear that changing the dynamics of men's role depends on changing the notions of manhood and the expectations for their agency (United Nations [UN], 2012). Men's self-stereotyping regarding their agency mediates the relationship between feeling a threat to their manhood and being willing to do housework (cf. Kosakowska-Berezecka et al., 2016a; Vandello \& Bosson, 2013).

Our findings accord with research on self-stigma conducted by Vogel et al. (2011). Self-stigma is an important cause which discourages men from seeking professional aid when it is needed. Seeking help is socially perceived as a presentation of weakness which is not congruent with the agentic masculinity 
model. Self-stigma can be described as the feeling of inferiority and weakness resulting from internalized, negative social views of illness and men who seek help (Vogel et al., 2011). Another study on a sample of males indicated that pressure to fulfil ideal of the real man contributes to mental illnesses, especially depression (Johnson et al., 2012). Additionally, Vogel et al. (2011) found that adherence to hegemonic masculine gender roles was correlated with more negative attitudes toward seeking psychological help and with generally lower willingness to seek aid. Therefore, self-judgments comprise an important topic for scholars and practitioners working with egalitarianism and men's health. Especially if gender incongruent behavior is seen negatively within men's larger society.

\section{BACKLASH AND HOUSEHOLD DUTIES}

The division of domestic duties depicts cultural understandings of masculinity and femininity that are built on gender prescriptions and proscriptions which limit women and men to performing gender-congruent activities (Heilman et al., 2004; Rudman et al., 2012). Hence, if men do get more involved in domestic work, they might be socially punished for breaking the rules of gender norms (backlash effects) (Rudman et al., 2012). Stay-at-home fathers devoted to their family suffer backlash in the form of social penalties for performing counter-stereotypical male roles (Rudman \& Fairchild, 2004; Rudman \& Mescher, 2013). Vandello, Hettinger, Bosson, and Siddiqi (2013) have also shown that men seeking work-life balance might be especially stigmatized in the eyes of others who see them as less masculine, more feminine, and probably less happy. In a study with Polish students using vignettes describing spouses (either male or female) who were financially dependent or independent of the other spouse, Roszak, Pałucka, and Rykaczewska (2012) showed that men who are financially independent are perceived as more satisfied with their life than men who are financially dependent on their wives. No such difference was observed in comparisons of financially dependent and independent women (Roszak et al., 2012). If staying at home and doing housework deprives men of financial independence, it might lead to their unhappiness.

Economic factors and social punishments prevent men from being more involved in housework, and as a result, men doing housework might be perceived as counter-stereotypical and of lower status (Rudman \& Phelan, 2010; Croft et al., 2015). According to the status incongruity hypothesis, it is the violation of status - rather than the violation of a specific gender role - that is most likely to result in backlash against the transgressor (e.g., Moss-Racusin et al., 2010; Rudman et al., 2012). Men focused on domestic duties rather than their professional career might thus be considered violators of the existing societal hierarchy (Eagly, Wood, \& Diekman, 2000; Moss-Racusin et al., 2010).

Other research has also shown that men who are viewed as almost exclusively family oriented might be perceived as having relatively low competence and agency, as shown by our results obtained in Poland (Kosakowska-Berezecka \& Karasiewicz, 2014). The loss of perceived agency and competence can be also a strong deterrent to western men, preventing them from being more involved at home (Vandello \& Bosson, 2013). Also requesting family leave to be more involved with the family can be detrimental for men's masculinity and productivity as employees (Brines, 1994; Vandello et al., 2013; Rudman \& Mescher, 2013) and thus threaten their manhood. Hence, doing housework deprives men of their masculinity, competence, agency, high status, productivity and happiness in the eyes of others - who would like that?

\section{WHY IS IT EASIER FOR MEN TO AVOID HOUSEHOLD DUTIES THAN FOR WOMEN?}

Professional careers and employment status seem to be good indicators of which partner takes up more household duties. The results of studies have shown that the partner who has more time after work engages the most at home (cf. Shelton \& John, 1996). Another influential factor is the difference in partners' earnings. Brines (1994) has shown that the partner with fewer economic resources (usually the woman) has little power or opportunity to negotiate who does household chores (Brines, 1994). As the gender pay gap shows, women who earn less thus are more involved in household duties (Öun, 2013). However, in countries which introduce dual-earner policies, women and men are expected to re-evaluate their views on household duties distribution (Öun, 2013).

Furthermore, fathers' type of employment influences the amount of time they spend with their children. Fathers employed part time or not employed spend more time with their children than those employed full time. However, working mothers spend more time with their children than working fathers. Additionally, when employment is increased by 1 hour more per week, it results in approximately 2.5 fewer hours spent with children (for both men and women) (Baxter, 2009). Wight, Raley, and Bianchi (2008) have also shown that fathers with an evening and night schedule spend significantly more time with their children than those employed on the day shift (Wight et al., 2008). Thus, untypical employment might give men more opportunities to engage in household chores.
Sharing housework can be healthy 
The division of domestic duties is the result of household bargaining, so married people with higher income and education use these advantages to increase their partner's share of housework while minimizing their own (Coltrane 2000; Fuwa 2004; Sanchez \& Thomson, 1997). Nevertheless, men who earn less than their female partners do not contribute more housework hours than men who earn the same or more than their female partners (Thébaud, 2010). In a universal pattern, a husband working 40 hours a week is $55 \%$ more likely to avoid feminine tasks than a man with no job. This gap between the male and female shares of household chores is especially noticeable when tasks are grouped in male-typed (agentic) and female-typed housework (Schneider, 2012). Treas and Tai (2010), who gathered data in 34 countries, described an almost universal division of chores into male-typed (yardwork, small repairs) and female-typed (laundry, meal preparation, cleaning, sick care, grocery shopping) chose. Another cross-cultural study by Treas and Tai (2010) showed that, in all cultures, men tend to avoid certain tasks, such as laundry, meal preparation, cleaning, sick care, and grocery shopping, which are seen as time-consuming and monotonous. In contrast, maletype tasks, such as home maintenance, car repair, and yard work, are seen as more recreational and episodic (Bianchi, Milkie, Sayer, \& Robinson, 2000). However, women's role in maintaining the gender gap within hours spent on housework also should not be overlooked.

A study by Holter et al. (2009) showed that, among cohabitating couples in Norway, tidiness standards are among the possible reasons for the unequal distribution of household duties among partners. More women than men agreed with the statement that they often think the home is too untidy, while only half as many men agreed (Holter et al., 2009). Women would even rather wash clothes themselves so that they know it is done properly (58\% of women think so in contrast to only $8 \%$ of men) (Holter et al., 2009). Hence, the standards for cleanliness in the house are maintained by mostly women; $60 \%$ of both men and women agree that it is the female partner who decides what is clean enough in the house. Holter et al. (2009) claimed that, as women adopt different tidiness standards than men, they view their contributions as lower and less valuable than men's declared contributions.

As women are already positioned as experts in household duties who know best in these matters, they tend to put their partners in the role of student (Żadkowska, 2011). Women often dictate to men what, when, and how they should do chores around the house, depriving them of responsibility for domestic duties (Sikorska, 2009). As a result, men's entry into domestic work can be also limited by female gatekeeping, or women exerting control over house- hold duties (Allen \& Hawkins, 1999; Connell, 2005). Thus, men do not engage fully in domestic duties because for women, it might mean losing their bastion of power (Titkow, Duch-Krzystoszek, \& Budrowska, 2004; Żadkowska, 2011).

Another factor which might influence men's involvement in the household is women's general perception of the fairness in duties division. If they consider the distribution of the duties to be fair, they do not encourage their partners to take part in them. Although this factor varies between countries, a general perception of equity is more common among women than the perception of inequality. A study conducted in 25 countries showed that, on average, $44.60 \%$ of women find the division of household duties to be fair to themselves (Braun, Lewin-Epstein, Stier, \& Baumgärtner, 2008). Conducting a cross-country comparison, Braun et al. (2008) reported that, "[i]n countries with a high gender-wage ratio, that is, where the advantage of men against women with regard to wages is less pronounced, the effect of an increasingly unequal division of labor in reducing the perception of equity is stronger" (p. 1153). Furthermore, women generally have more positive attitudes toward undertaking household duties and associate them with greater enjoyment, higher standards, and feelings of responsibility (Poortman \& van der Lippe, 2009).

Women's higher standards of cleanliness, gatekeeping function, and unawareness of the unfairness of the division of labor might influence men's unwillingness to engage in those activities. Women should appear to be clever, encouraging, reinforcing motivators of men's gender-equal participation in household maintenance. If women do not, it might backfire on them as they do not accomplish the equal division of household duties.

\section{WHY IS IT WORTHWHILE FOR A MAN TO SHIFT FROM GENDER STEREOTYPES?}

One area of men's involvement in domestic work is parenting-related duties. Since the late twentieth century, fatherhood and the father's active role in the family have become important matters of social concern in European and North American culture (Astone \& Peters, 2014). The evolving new man is an aware, involved parent (Duyvendak \& Stavenuiter, 2004) interested in reconciling work and family life (Vandello et al., 2013). One manifestation of the changing concept of fatherhood is the increasing number of men who are both fathers and employees and wish to take parental leave (Lammi-Taskula, 2008).

So far, scientific findings have pointed to the beneficial outcomes of fathers' involvement in the upbringing of children for childcare in general (Astone 
\& Peters, 2014) but also for men's health. Specifically, parenthood has been found to be a moderating factor which significantly lowers blood pressure among men (Holt-Lunstad, Smith, \& Layton, 2010). Moreover, fatherhood resulted in mental and social benefits documented in studies on a group of parents (McKeering \& Pakenham, 2000; Lammi-Taskula, 2008; Wiesmann, Boeije, van Doorne-Huiskes, \& den Dulk, 2008; O’Neill, McCaughan, Semple, \& Ryan, 2013). McKeering and Pakenham (2000) found that parental generativity resulted in societal generativity. In Nordic countries, parental duties are considered to be opportunities to develop one's professional, personal, and family life (Lammi-Taskula, 2008).

At the same time, limitations to the positive link between the egalitarian family care model and men's increased well-being should be considered. Fatherhood can be advantageous to a man's health, but health is also controlled by other factors, such as the stress associated with supporting a family. For example, the UN (2011) reported that men's risk of heart disease increased by $12 \%$ in relation to family size (in cases with more than 2 children). Engelman, Agree, Yount, and Bishai (2010) identified culture-specific issues which play important moderating roles in health benefits; for example, in Egypt, where the sex preference for male children is high, fatherhood of daughters was linked to poorer health. Moreover, the complexity within variables should be taken into consideration. For example, married fathers are generally healthier and wealthier than non-married fathers, but it has not been investigated whether becoming a married father is the factor influencing the positive outcome or whether the positive effect is simply due to the advantageous circumstances of men who become married fathers (Astone \& Peters, 2014).

As well, being on parental leave can offer a significant break from work and thus positively influence the father's mental health due to the self-perceived responsibility for family and fulfilment of the social pressure to take care of one's family. Men often consider their work to be burdensome, so parental leave offers the opportunity to avoid professional chores and work-related stress (Humberd, Ladge, \& Harrington, 2015). Involved fathers have stronger social bonds with their children, partners, extended family, and in-laws (Astone \& Peters, 2014). Moreover, Eggebeen, Knoester, and McDaniel (2012) suggested that fathers tend to refrain from risky behaviors which are stereotypically male (e.g. displays of power, sexual conquest behaviors). In general, fathers appear to be healthier and to have longer life expectancy than other men (Astone \& Peters, 2014). These observed changes in the concept of manhood seem to be slowly changing the dominant masculinity model and thus could result in improved male health, a smaller gender gap in mental illnesses, and longer life of expectancy for men (EIGE, 2012).
According to Bekkengen (2002), the new fatherhood encompasses of fathers' engagement in the practical, everyday care of children to the same extent as mothers. However, Bekkengen (2002) also posited that greater involvement as fathers is not necessarily followed by more involvement in other domestic tasks, such as housework, another crucial element in fostering gender equality within households. On the other hand, paid paternity leave is considered to be a fast track to more male involvement in care (Kotsadam \& Finseraas, 2011). Paid parental leaves helps men to be more involved in household duties; for example, fathers on paid parental leave are more involved in childcare and more willingly participate in household duties (Reich, Boll, \& Leppin, 2012). Various studies have also shown that longer leave fosters greater involvement in childcare; hence, the longer men's parental leave is, the more visible their participation in childcare is, the more willing they are to take care of children alone (without the assistance of mothers), and the more satisfaction they derive from time spent with their children (Haas \& Hwang, 2008). Fuwa and Cohen (2007) have also shown that the longer leave is, the more equal the division of housework between partners is.

Involvement in household duties is also associated with health benefits for partners. Men's more active role in household chores has desired results for women's health because it decreases the time that women spend on household maintenance and family care. Such a positive change might, in turn, be related to women's relationship satisfaction (UN, 2011). Even a minor contribution to the work around the house provided by a man is perceived by his female partner as a sign of respect and care and can increase her relationship satisfaction (Gager, 1998; Tai \& Treas, 2013). Women who claim that their husbands are not involved enough in household duties are less satisfied (Frisco \& Williams, 2003; Stevens, Kiger, \& Riley, 2001; Wilkie, Ferree, \& Ratcliff, 1998), more depressed (Bird, 1999), and more likely to resort to divorce (Frisco \& Williams, 2003) than women whose partners share household tasks. It is important to highlight that the husband's mere demonstration of the willingness to do feminine tasks rather than how much he actually does influences women's perception of relationship quality (Thompson, 1991; Spitze \& Loscocco, 2000; Ruppanner, 2008). This finding indicates that even declared equality within household division might not be manifested in the actual division of tasks (Giddens, 1992; Beck \& Beck-Gernsheim, 2004). The standards of what is considered to be the equal division of housework varies across countries depending on the level of gender equality present in a given context.
Sharing housework can be healthy 


\section{CHANGING CULTURES, CHANGING GENDER ROLES, AND SIGNS OF SOCIAL CHANGE}

Both European Union reports and a substantial body of research and literature indicate that men's greater involvement in domestic and childcare benefits women's career development and has positive effects on men's health and on children's social, emotional, and cognitive functioning (cf. Bartlett, 2004; Eurostat, Natasza $\quad$ 2013; Engle, Beardshaw, \& Loftin, 2006; Richter, 2006). Kosakowska- As changing cultural contexts can make perceptions Berezecka, Lubomiła Korzeniewska, Marta Kaczorowska of gender roles more neutral (Oyserman, 2011) compare household maintenance patterns among men who migrate from less-gender egalitarian to more gender-egalitarian country might shed light on the factors fostering the transformation toward an egalitarian-partnership model of the family, with both partners involved in domestic work.

In our PAR Migration Navigator project during the period between 2013-2016 we explored the practices of gender equality related to individual well-being within the households of Polish couples living in Poland, Polish migrant couples living in Norway, and Norwegian couples living in Norway. In this way, we compared couples living in two countries with visibly different gender-equality levels. Additionally, we compared Polish couples living in these two countries, which allowed us to compare the practices of couples who have similar cultural backgrounds but live in social systems with different approaches to gender equality (Żadkowska, Kosakowska-Berezecka, \& Ryndyk, 2016).

Poland is a country less gender egalitarian than Norway. In Poland, there is a visible, stereotypical division of domestic duties (Chrzan-Dętkoś, Kosakowska-Berezecka, \& Pawlicka, 2011; Gwizdała, 2013; Szczepańska, 2006) as Polish men tend to take a secondary role in childcare and domestic duties (cf. Kosakowska-Berezecka, Pawlicka, \& KalinowskaŻeleźnik, 2012; Mikołajczak \& Pietrzak, 2015; Żadkowska, 2011). Polish women spend on as average of 296 minutes daily on housework and caring for family members, but men an average of 157 minutes daily (Organization for Economic Cooperation and Development (OECD), Better Life Index, 2014). Norwegian men contribute more to housework and related chores (OECD) (Better Life Index, 2014). Norwegian men spend 180 minutes a day doing housework (their female partners still spend 210 minutes) and thus have one of the highest scores for time spent on housework among the 34 countries analyzed in the report.

In one of our studies we conducted in-depth interviews with a sample of highly educated, dual-income Polish migrant couples including: 19 heterosexual couples, mixed couples in region of Rogaland,
Norway (3 couples, Polish women and Norwegian men), Polish citizens living in the Pomerania region (21 couples), mixed couples in Pomerania (4 couples, Polish women and Norwegian men) and Norwegians living in the same region as Polish migrants (3 couples). All interviewees cohabitated, and not all were married. Their ages ranged from 22 to 53 , and the average age was 31 . The interviewed families had 1,2 or 3 children. The first round of data collection (100 individual interviews and 100 joint interviews) showed that Polish migrant men desired a dual-career model in their marriages. In contrast, a comparable sample of fathers in Poland did not approve of gender-egalitarian practices within their relationships. Polish men in Norway also declared that their family life improved greatly after migration from Poland to Norway. Their greater involvement in household duties and childcare in Norway were supported by their working environment and social system (Żadkowska et al., 2016) because achieving gender equality within households is considered to be a norm in Norwegian society and men who are involved in housework are not seen as gender-norm violators. This result was also confirmed in an experimental study conducted among Norwegian and Polish students (Kosakowska-Berezecka, Safdar, Jurek, \& Bhardwaj, 2016d) in which they were asked to rate men in communal roles. We showed that men who were exclusively occupied in household maintenance and child care did not lose status in the eyes of others and are socially accepted - but only among Norwegian students (Kosakowska-Berezecka et al., 2016d). Thus, Polish fathers who migrated with their families to Norway enjoyed better opportunities to be more engaged in fatherhood and household duties. This behavior was considered to be less gender incongruent in Norway and did not lead to the backlash effect.

Additionally, family policies in Norway support such behaviors. Fathers in Norway are offered 1 month of non-transferable, paid leave out of a total of 11 months' parental leave, and the father's pay during leave is based on his previous income, not the mother's. As a result, in 2014, $89 \%$ of fathers in Norway used parental leave (International Labour Standards [ILO], 2014). Polish men in Norway perform more household duties than Norwegian men in Norway (Kosakowska-Berezecka, Jurek, Besta, Korzeniowska, \& Seibt, 2016e). As well, compared to Polish men in Poland, Polish men in Norway give less gendered descriptions of domestic tasks, are more willing to be involved fathers, and seem to follow a gender-egalitarian division of household duties (Żadkowska et al., 2016). This cooperative approach to household duties is fostered by attribution of a less-gendered meaning to domestic labor in Norway and changes in views on gender identity. Polish men in Norway seem to have an increased sense of masculinity as they earn more in Norway 
and, similarly to Norwegians, tend to view domestic duties in a more gender neutral way (cf. Kosakowska-Berezecka et al., 2016e). Consequently, Polish men living in Norway tend to do more at home (Żadkowska et al., 2016).

These findings show that gender roles are not built on fixed, universal norms that impose demands on men and women from a given society but are a flexible set of activities, created through interactions and shaped by the given cultural context. Thus, when men see that men and women can perform similar tasks they might perceive housework as less feminine. As a result, they potentially see engaging in these activities as a lesser threat to their masculinity. This was confirmed in our another study where our participants read a short scientific text either emphasizing stereotypical gender differences or showing evidence that there are no such differences. Results indicated that in the "no differences" condition, men showed lower acceptance of gender inequality and a greater willingness to engage in domestic activities (Study 3, Kosakowska-Berezecka et al., 2016a).

Hence, more gender-neutral perceptions of the world might lead to more gende-netural perception of domestic work might and this might be an important factor in encouraging more men to cleaning the flat and be more involved in household maintenance. And have beneficial effects for men's health.

\section{CONCLUDING REMARKS}

Policies specifically directed at men are necessary initiatives to foster gender equality and health equity among women and men. Individual men have important roles to advocate and stand for women's rights because doing so promote gender equality as an advantageous model both for women and men (WHO, 2010).

Another important need is to teach couples how to negotiate the division of household duties. The unequal distribution of household labor is correlated with low psychological well-being and family conflict, making negotiations concerning household and family duties an important health-related issue (Kil \& Neels, 2014; Lammi-Taskula, 2008). Often, these negotiations concerning the demands of working and raising a family can be overwhelmed by gendered assumptions about who is expected to perform a certain task, who sets the standards of cleanliness, and who evaluates what in the house (Klein, Izquierdo, \& Bradbury, 2007). Research results concerning communication between couples when deciding the division of domestic work show that the transition to parenthood is a critical moment in the development of unequal time spent on household maintenance; therefore, such negotiations should take place as quickly as possible (Katz-Wise, Priess, \& Hyde, 2010).
However, more research is needed in this area (KatzWise et al., 2010).

Another important implication for future policies is the need to put more emphasis on men. Although the majority of gender-equality efforts are aimed at women, our literature review and the results of our studies show that men's lack of involvement in household duties might suppress further steps to accomplishing gender equality in the family and society. Holter's (2014) "emerging culture of gender equality" (p. 541) could lead to the improvement of both men's and women's health and well-being. Highlighting men's benefits from gender egalitarianism and the gender-equality progress achieved due to men's involvement is thus of crucial importance and should be an important area for scholars and practitioners working with men's health.

Educational programs should also teach the ability to avoid gender stereotypes when sharing household duties. An example of such an education program can be found in the PAR Migration Navigator manuals for couples and for trainers who work with couples in workshops (Kosakowska-Berezecka et al., 2016b; Kosakowska-Berezecka, Żadkowska, Gajewska, Wroczyńska, \& Znaniecka, 2016c). In these publications, we present a set of chapters dedicated to different areas of skills useful in effective negotiations concerning household duties division (stress management, conflict resolution and communication skills, gender stereotypes and different family models influencing division of housework, intimacy and happiness in couples' life). Participation in a workshop based on this method might lead couples to negotiate who does what at home instead of following implicit assumptions about housework (Kosakowska-Berezecka et al., 2016c). Then seeing a man cleaning a flat on with a comparable frequency as women are seen might not be so unexpected. First, though, both men and women need to see the benefits of men's involvement in household maintenance.

The research leading to these results has received funding from the Polish-Norwegian Research Programme operated by the National Centre for Research and Development under the Norwegian Financial Mechanism, 2009-2014 in the frame of Project Contract Pol-Nor/202343/62/2013.

\section{References}

Allen, S. M., \& Hawkins, A. J. (1999). Maternal gatekeeping: Mothers' beliefs and behaviors that inhibit greater father involvement in family work. Journal of Marriage and the Family, 61, 199-212.

Amanatullah, E. T., \& Morris, M. W. (2010). Negotiating gender roles: gender differences in assertive negotiating are mediated by women's fear
Sharing housework can be healthy 
of backlash and attenuated when negotiating on behalf of others. Journal of Personality and Social Psychology, 98, 256-267.

Astone, N. M., \& Peters, H. E. (2014). Longitudinal influences on men's lives: research from the transition to fatherhood project and beyond. Fathering, 12, 161-173.

Bartlett, E. (2004). The effects of fatherhood on the health of men: a review of the literature. Journal of Men's Health and Gender, 1, 159-169.

Natasza KosakowskaBerezecka,

Lubomiła Korzeniewska, Marta Kaczorowska

Baxter, J. (1992). Power attitudes and time: The domestic division of labour. Journal of Comparative Family Studies, 23, 165-182.

Baxter, J. (2009). Parental time with children. Do job characteristics make a difference? Australian Institute of Family Studies. Retrieved from: https:// aifs.gov.au/publications/parental-time-children-do-job-characteristics-make-d/summary

Beck, U., \& Beck-Gernsheim, E. (2004). Families in a runaway world. In S. Jacqueline, J. Treas, \& M. Richards (eds.), The Blackwell Companion to the Sociology of Families (pp. 498-514). Malden: Blackwell Publishing.

Bekkengen, L. (2002). Man far valja: Om foraldraskap och faraldraledighet i arbetsliv och familjeliv [Men can choose - about parenthood and parental leave in working life and family life]. Stockholm: Liber.

Bianchi, S. M., Milkie, M. A., Sayer, L. C., \& Robinson, J. P. (2000). Is anyone doing the housework? Trends in the gender division of household labor. Social Forces, 79, 191-228.

Bianchi, S. M., Robinson, J. P., \& Milkie, M. (2006). Changing rhythms of American family life. New York: Russell Sage Foundation.

Bird, C. E. (1999). Gender, household labor, and psychological distress the impact of the amount and division of housework. Journal of Health and Social Behavior, 40, 32-45.

Bonke, J., \& Jensen, B. (2012). Paid and unpaid work in Denmark - Towards gender equity. International Journal of Time Use Research, 9, 108-119.

Bosson, J. K., \& Vandello, J. A. (2011). Precarious manhood and its links to action and aggression. Current Directions in Psychological Science, 20, 82-86.

Braun, M., Lewin-Epstein, N., Stier, H., \& Baumgärtner, M. K. (2008). Perceived equity in the gendered division of household labor. Journal of Marriage and Family, 70, 1145-1156.

Brines, J. (1994). Economic dependency, gender, and the division of labor at home. American Journal of Sociology, 100, 652-688.

Caswell, T. A., Bosson, J. K., Vandello, J. A., \& Sellers, J. G. (2014). Testosterone and men's stress responses to gender threats. Psychology of Men \& Masculinity, 15, 4-11.

Chrzan-Detkos, M., Kosakowska-Berezecka, N., \& Pawlicka, P. (2011). Women, men and second shift-psychological determinants of work-life balance. Polish Journal of Social Sciences, 6, 123-140.

Coltrane, S. (2000). Research on household labor: modelling and measuring the social embeddedness of routine family work. Journal of Marriage and the Family, 62, 1208-1233.

Connell, R. W. (2005). Change among the gatekeepers: men, masculinities, and gender equality in the global arena. Journal of Women in Culture and Society, 30, 1801-1825.

Croft, A., Schmader, T., \& Block, K. (2015). An underexamined inequality: Cultural and psychological barriers to men's engagement with communal roles. Personality and Social Psychology Review, 19, 343-370.

Cuddy, A., Wolf, E., Glick, P., Crotty, S., Chong, J., \& Norton, M. I. (2015). Men as cultural ideals: cultural values moderate gender stereotype content. Journal of Personality and Social Psychology, 109, 622-635.

Duyvendak, J. W., \& Stavenuiter, M. (2004). Working fathers, caring men. reconciliation of working life and family life. Retrieved from: http://www. policy.hu/takacs/courses/matters/Working-Fathers-2004-7-31.pdf

Eagly, A. H., Wood, W., \& Diekman, A. B. (2000). Social role theory of sex differences and similarities: A current appraisal. In T. Eckes \& H. M. Trautner (eds.), The developmental social psychology of gender (pp. 123-174). Mahwah, NJ: Erlbaum.

Eggebeen, D., Knoester, C., \& McDaniel, B. (2012). The implications of fatherhood for men. In N. Cabrera \& C. S. Tamis-LeMonda (eds.), Handbook of father involvement: multidisciplinary perspectives ( $2^{\text {nd }}$ ed.) (pp. 338-357). New York, NY: Rutledge.

Engelman, M., Agree, E. M., Yount, K. M., \& Bishai, D. (2010). Parity and parents' health in later life: The gendered case of Ismailia, Egypt. Population Studies, 64, 165-178.

Engle, P., Beardshaw, T., \& Loftin, C. (2006). The child's right to shared parenting. In L. Richter \& R. Morrell (eds.), Baba: Men and fatherhood in South Africa (pp. 293-305). Cape Town: HSRC Press.

European Institute for Gender Equality (EIGE) (2012). The Involvement of Men in Gender Equality Initiatives in the European Union. Luxembourg: Publications Office of the European Union.

Eurostat. (2013). Sustainable development in the European Union. Statistical Books, 76-90.

Frisco, M. L., \& Williams, K. L. (2003). Perceived housework equity, marital happiness, and divorce in duel-earner households. Journal of Family $I_{s}$ sues, 24, 51-73.

Fuwa, M. (2004). Macro-level gender inequality and the division of household labor in 22 countries. American Sociological Review, 69, 751-767. 
Fuwa, M., \& Cohen, P. N. (2007). Housework and Social Policy. Social Science Research, 36, 512-530.

Gager, C. (1998). The role of valued outcomes, justifications, and comparison referents in perceptions of fairness among dual-career couples. Journal of Family Issues, 19, 622-648.

Geist, C. (2005). The welfare state and the home: regime differences in the domestic division of labor. European Sociological Review, 21, 23-41.

Giddens, A. (1992). The Transformation of Intimacy: Sexuality, Love and Eroticism in Modern Societies. Cambridge: Polity Press.

Glick, P., \& Fiske, S. T. (2001). An ambivalent alliance: Hostile and benevolent sexism as complementary justifications for gender inequality. American Psychologist, 56, 109-118.

Gwizdała, M. (2013). Gender equality? Publish Opinion Research Center. Retrieved from: http://www. cbos.pl/SPISKOM.POL/2006/K_184_06.PDF $\quad\left(20^{\text {th }}\right.$ July 2014).

Haas, L., \& Hwang, C. P. (2008) The impact of taking parental leave on fathers' participation in childcare and relationships with children: lessons from Sweden. Community, Work \& Family, 11, 85-104. doi: 10.1080/13668800701785346

Heilman, M. E., Wallen, A. S., Fuchs, D., \& Tamkings, M. M. (2004). Penalties for success: Reactions to women who succeed at male gender-typed tasks. Journal of Applied Psychology, 89, 416-427.

Holt-Lunstad, J., Smith, T. B., \& Layton, J. B. (2010). Social relationships and mortality risk: a meta-analytic review. PLoS Med, 7, e1000316. doi: 10.1371/ journal.pmed.1000316

Holter, Ø. G. (1997). Gender, Patriarchy and Capitalism - A Social Forms Analysis. Oslo: University of Oslo.

Holter, Ø. G. (2014). What's in it for men? Old question, new data. Men and Masculinities, 17, 515-548. doi: $10.1177 / 1097184 X 14558237$

Holter, Ø. G., Svare, H., \& Egeland, C. (2009). Gender Equality and Quality of Life - A Norwegian Perspective. Oslo: NIKK (Nordic Gender Institute).

Humberd, B., Ladge, J. J., \& Harrington, B. (2015). The "New" Dad: Navigating Fathering Identity Within Organizational Contexts. Journal of Business and Psychology, 30, 249-266.

International Labour Organization. (2014). International Labour Standards. Retrieved from: http:// www.ilo.org/wcmsp5/groups/public/---ed norm/---normes/documents/genericdocument/ wcms_230305.pdf

Johnson, J. L., Oliffe, J. L., Kelly, M. T., Galdas, P., \& Ogrodniczuk, J. S. (2012). Men's discourses of help-seeking in the context of depression. Sociology of Health \& Illness, 34, 345-361.

Kan, M. Y., O’Sullivan, O., \& Gershuny, J. (2011). Gender convergence in domestic work: Discerning the effect of interactional and institutional barriers from large-scale data. Sociology, 45, 234-251.

Katz-Wise, S. L., Priess, H. A, Hyde, J. S. (2010). Gender-role attitudes and behavior across the transition to parenthood. Developmental Psychology, 46, 18-28.

Kil, T., \& Neels, K. (2014). Gender Inequality in the Division of Housework over the Life Course: a European Comparative Perspective. Paper presented at the European Population Conference. Budapest, Hungary. Retrieved from: http://epc2014.princeton.edu/papers/140493

Klein, W., Izquierdo, C., \& Bradbury, T. N. (2007). Working relationships: communicative patterns and strategies among couples in everyday life. Qualitative Research in Psychology, 4, 29-47. doi: 10.1080/14780880701473391

Kosakowska-Berezecka, N., Besta, T., Adamska, K., Jaśkiewicz, M., Jurek, P., \& Vandello, J. (2016a). If my masculinity is threatened i won't support gender equality? the role of agentic self-stereotyping in restoration of manhood and perception of gender relations. Psychology of Men \& Masculinity, 17, 274-284. doi: 10.1037/ men0000016

Kosakowska-Berezecka, N., \& Karasiewicz, K. (2014). Jestem unikalny, więc cenię Twoją unikalność? Wpływ aktywizacji tożsamości osobistej i społecznej na postrzeganie innych - porównanie międzykulturowe Polska-Indie [I am unique therefore I appreciate your uniqueness? Effects of personal and social identity priming on judgments of others: A cross-cultural comparison of Poland and India]. Psychologia Spoteczna, 9/1, 54-67. doi: 10.7366/189618002014280104

Kosakowska-Berezecka, N., Pawlicka P., \& Kalinowska-Żeleźnik, A. (2012). New female roles versus gender stereotypes - situation of women in the public sphere. In M. Lipowski \& Nieckarz Z. (eds.), Empirical Aspects of the Psychology of Management (pp. 175-227). Gdynia: Wydawnictwo Wyższej Szkoły Administracji i Biznesu im. Eugeniusza Kwiatkowskiego.

Kosakowska-Berezecka, N., Żadkowska, M., Gajewska, M., Wroczyńska, A., \& Znaniecka, M. (2016b). Navigator for couples. Manual for Couples. Wydawnictwo Uniwersytetu Gdańskiego. http://migrationnavigator.org/ftp/Couplesnavigator.pdf

Kosakowska-Berezecka, N., Żadkowska, M., Gajewska, M., Wroczyńska, A., \& Znaniecka, M. (2016c). course on work-life balance for couples. manual for educators. Wydawnictwo Uniwersytetu Gdańskiego. http://migrationnavigator.org/ftp/ Manualfortrainers.pdf

Kosakowska-Berezecka, N., Safdar, S., Jurek, P., \& Bhardwaj, G. (2016d, paper to be submitted). Men in Communal Roles: Evaluations of norm violators in Canada, Norway, Poland \& India.

Kosakowska-Berezecka, N., Jurek, P., Besta, T., Korzeniewska, L., \& Seibt, B. (2016e, paper to be
Sharing housework can be healthy 
submitted). De-gender them! Gendered division of household labour and men's willingness to share it - cross-cultural comparison of Polish and Norwegian male students.

Kotsadama, A., \& Finseraas, H. (2011). The state intervenes in the battle of the sexes: Causal effects of paternity leave. Social Science Research, 40, 1611-1622.

Lammi-Taskula, J. (2008). Doing fatherhood: understanding the gendered use of parental leave in Finland. Fathering, 6, 133-148.

Natasza

KosakowskaBerezecka,

Lubomiła Korzeniewska, Marta

Kaczorowska

Laurin, K., Kay, A. C., \& Shepherd, S. (2011). Self-stereotyping as a route to system justification. Social Cognition, 29, 360-375.

McKeering, H., \& Pakenham, K. I. (2000). Gender and generativity issues in parenting: do fathers benefit more than mothers from involvement in child care activities? Sex Roles, 43, 459-480.

Mikołajczak, M., \& Pietrzak, J. (2015). A broader conceptualization of sexism: the case of Poland. In S. Safdar \& N. Kosakowska-Berezecka (eds.), Psychology of Gender Through the Lens of Culture: Theories and Applications (pp. 169-192). New York: Springer.

Moss-Racusin, C. A., Phelan, J. E., \& Rudman, L. A. (2010). When men break the gender rules: status incongruity and backlash against modest men. Psychology of Men \& Masculinity, 11, 140-151.

OECD Better Life Index. (2014). OECD Publishing. Retrieved from: http://www.oecdbetterlifeindex. org/countries/canada/

O’Neill, C., McCaughan, E., Semple, C., \& Ryan, A. (2013). Fatherhood and cancer: a commentary on the literature. European Journal of Cancer Care, 22, 161-168.

Oyserman, D. (2011). Culture as situated cognition: Cultural mindsets, cultural fluency, and meaning making. European Review of Social Psychology, 22, 164-214.

Oun, I. (2012). Work-family conflict in the nordic countries: a comparative analysis. Journal of Comparative Family Studies, 43, 165-184.

Oun, I. (2013). Is it fair to share? perceptions of fairness in the division of housework among couples in 22 countries. Social Justice Research, 26, 400-421.

Poortman, A., \& Van der Lippe, T. (2009). Attitudes toward housework and child care and the gendered division of labor. Journal of Marriage and Family, 71, 526-541.

Prentice, D. A., \& Carranza, E. (2002). What women and men should be, shouldn't be, are allowed to be, and don't have to be: the contents of prescriptive gender stereotypes. Psychology of Women Quarterly, 26, 269-281.

Reich, N., Boll, Ch., \& Leppin, J. S. (2012). Fathers' childcare and parental leave policies: Evidence from Western European Countries and Canada. HWWI Research Papers 115, Hamburg Institute of International Economics (HWWI).
Richter, L. (2006). The importance of fathering for children. In L. Richter \& R. Morrell (eds.), Baba: Men and fatherhood in South Africa (pp. 53-69). Cape Town: HSRC Press.

Roszak, J., Pałucka, R., \& Rykaczewska, K. (2012). O zadowolonej kobiecie sukcesu i jej niezbyt szczęśliwym partnerze, czyli jak (nie)zależność finansowa w związku wpływa na postrzeganą satysfakcję życiową kobiet i mężczyzn [On satisfied successful woman and her not-so-satisfied partner - how financial (in)dependence influences the perception of women's and men's satisfaction with life]. In A. Chybicka, N. Kosakowska-Berezecka, \& P. Pawlicka (eds.), Podróże między kobiecościq a męskościq [Journeys between femininity and masculinity] (pp. 39-58). Kraków: Oficyna Wydawnicza "Impuls".

Rudman, L. A., \& Fairchild, K. (2004). Reactions to counterstereotypic behavior: the role of backlash in cultural stereotype maintenance. Journal of Personality and Social Psychology, 87, 157-176.

Rudman, L. A., \& Mescher, K. (2013). Penalizing men who request a family leave: is flexibility stigma a femininity stigma? Journal of Social Issues, 69, 322-340.

Rudman, L. A., Moss-Racusin, C. A., Phelan, J. E., \& Nauts, S. (2012). Status incongruity and backlash effects: Defending the gender hierarchy motivates prejudice against female leaders. Journal of Experimental Social Psychology, 48, 165-179.

Rudman, L. A., \& Phelan, J. E. (2010). The effect of priming gender roles on women's implicit gender beliefs and career aspirations. Social Psychology, 41, 192-202.

Ruppanner, L. E. (2008). Fairness and housework: a cross-national comparison. Journal of Comparative Family Studies, 39, 509-526.

Sanchez, L., \& Thomson, E. (1997). Becoming mothers and fathers: Parenthood, gender and the division of labor. Gender and Society, 11, 747-762.

Scambor, E., Wojnicka, K., \& Bergmann, N. (2013). The role of men in gender equality - European strategies \& insights. Luxembourg: Publications Office of the European Union.

Schneider, D. (2012). Gender deviance and household work: the role of occupation. American Journal of Sociology, 17, 1029-1072.

Shelton, B. A., \& John, D. (1996). The division of household labor. Annual Review of Sociology, 22, 299-322.

Sikorska, M. (2009). Nowa matka, nowy ojciec, nowe dziecko. O nowym układzie sit w polskich rodzinach [New mother, new father, new child. On new relations of power among Polish families]. Warszawa: Wydawnictwa Akademickie i Profesjonalne.

Spitze, G., \& Loscocco, K. A. (2000). The labor of sisyphus? Women's and men's reactions to housework. Social Science Quarterly, 81, 1087-1100.

Stevens, D., Kiger, G., \& Riley, P. J. (2001). Working hard and hardly working: domestic labor and 
marital satisfaction among dual-earner couples. Journal of Marriage and Family, 63, 514-526.

Strier, H., \& Lewin-Epstein, N. (2007). Policy effects on the division of housework. Journal of Comparative Policy Analysis, 9, 235-259.

Szczepańska, J. (2006). Men and women and share of household duties. Public Opinion Research Center. Retrieved from: http://www.cbos.pl/SPISKOM. POL/2006/K_184_06.PDF (20 th July 2014).

Tai, T., \& Treas, J. (2013). Housework task hierarchies in 32 countries. European Sociological Review, 29, 780-791.

Thébaud, S. (2010). Masculinity, bargaining, and breadwinning: understanding men's housework in the cultural context of paid work. Gender and Society, 24, 330-354.

Thévenon, O. (2011). Family policies in OECD countries: a comparative analysis. Population and Development Review, 37, 57-87.

Thompson, L. (1991). Family work: women's sense of fairness. Journal of Family Issues, 12, 181-196.

Titkow, A., Duch-Krzystoszek, D., \& Budrowska, B. (2004). Nieodplatna praca kobiet. Mity, realia, perspektywy [Unpaid work of women. Myths, reality and perspectives]. Warszawa: Wydawnictwo Instytutu Filozofii i Socjologii PAN.

Treas, J., \& Tai, T. (2010). Real Men Don't Do Laundry? Avoidance of Female-Typed Household Tasks in 34 Countries. Paper presented at the annual meeting of the American Sociological Association Annual Meeting, Hilton Atlanta and Atlanta Marriott Marquis, Atlanta, GA.

United Nations. (2011). Men in Families and Family Policy in a Changing World. Retrieved from: http://www.un.org/esa/socdev/family/docs/ men-in-families.pdf

United Nations. (2012). Men in Families and Family Policy in a Changing World. Retrieved from: http://www.un.org/esa/socdev/family/docs/ men-in-families.pdf

Vandello, J. A., \& Bosson, J. K. (2013). Hard won and easily lost: A review and synthesis of theory and research on precarious manhood. Psychology of Men \& Masculinity, 14, 101-113. doi: 10.1037/a0029826

Vandello, J. A., Bosson, J. K., Cohen, D., Burnaford, R. M., \& Weaver, J. R. (2008). Precarious manhood. Journal of Personality and Social Psychology, 95, 13251339.

Vandello, J. A., Hettinger, V. E., Bosson, J. K., \& Siddiqi, J. (2013). When equal really isn't equal: The masculine dilemma of seeking work flexibility. Journal of Social Issues, 69, 303-321.

Vogel, D. L., Heimerdinger-Edwards, S. R., Hammer, J. H., \& Hubbard, A. (2011). "Boys don't cry": examination of the links between endorsement of masculine norms, self-stigma, and help-seeking attitudes for men from diverse backgrounds. Journal of Counselling Psychology, 58, 368-382.
Voicu, M., Voicu, B., \& Strapcova, K. (2009). Housework and gender inequality in European countries. European Sociological Review, 25, 365-377.

Wiesmann, S., Boeije, H., van Doorne-Huiskes, A., \& den Dulk, L. (2008). "Not worth mentioning": The implicit and explicit nature of decision-making about the division of paid and domestic work. Community, Work \& Family, 11, 341-363.

Wilkie, J. R., Ferree, M. M., \& Ratcliff, K. S. (1998). Gender and fairness: marital satisfaction in two-earner couples. Journal of Marriage and the Family, 60, 577-594.

Wight, V., Raley, S., \& Bianchi, S. (2008). Time for children, one's spouse and oneself among parents who work nonstandard hours. Social Forces, 87, 2-28.

Wood, W., \& Eagly, A. H. (2010). Gender. In S. T. Fiske, D. T. Gilbert, \& G. Lindzey (eds.), Handbook of social psychology (pp. 629-667). New York: Wiley.

Wood, W., \& Eagly, A. H. (2012). Biosocial construction of sex differences and similarities in behavior. In J. M. Olson \& M. P. Zanna (eds.), Advances in experimental social psychology (pp. 55-123). London, UK: Elsevier.

World Health Organization. (2010). Policy approaches to engaging men and boys in achieving gender equality and health equity. Retrieved from: http:// www.who.int/gender-equity-rights/knowledge/9789241500128/en/

Yodanis, C. (2010). The institution of marriage. In J. Treas \& S. Drobnič (eds.), dividing the domestic: men, women, and household work in cross-national perspective (pp. 175-191). Stanford: Stanford University Press.

Żadkowska, M. (2011). Mąż uczniem żony. O podziale obowiązków domowych na podstawie socjologii pary Jeana-Claude'a Kaufmanna [Husband - a wife student. Domestic duties division according to Jean-Claude Kaufmann sociology of couple]. In M. Świątkiewicz-Mosny (ed.), Rodzina - kondycja i przemiany [Family conditions and family changes] (pp. 89-101). Kraków: Wydawnictwo Uniwersytetu Jagiellońskiego.

Żadkowska, M., Kosakowska-Berezecka, N., \& Ryndyk, O. (2016, in press). Two worlds of fatherhood - comparing the use of parental leave among Polish fathers in Poland and in Norway. In K. Slany, E. Guriye, P. Pustułka, \& M. Ślusarczyk (eds.), Transnational Polish families in Norway: social capital, integration, institutions and care. Warsaw: Peter Lang International Academic Publishers (2016, forthcoming).
Sharing housework can be healthy 